\title{
Assessing genetic Variability in Malt Barley (Hordeum distichon L.) Genotypes in Southeastern Ethiopia
}

\author{
Workineh Mekasa Buli ${ }^{1 *}$ and Hussein Mohammed Ali $^{2}$ \\ ${ }^{I}$ Ethiopian Institute of Agricultural Research, Addis Ababa, Ethiopia. \\ ${ }^{2}$ Hawassa University, Hawassa, Ethiopia.
}

*Corresponding Authors: Workineh Mekasa Buli, Ethiopian Institute of Agricultural Research, Addis Ababa, Ethiopia.

\begin{abstract}
A total of 20 malt barley genotypes were evaluated using complete Block Design in four replications at two locations in Southeastern Ethiopia during 2015 main cropping season, which lapsed from July to December. The study was conducted to assess the total variability present within the evaluated genotypes. The combined analysis of variance showed that there were significant differences among the tested genotypes for days to heading, days to maturity, grain yield, fertile tillers per plant, total tillers per plant, spike length and number of kernels per spike $(P<0.001)$. The analysis of variance for malting quality characters showed highly significant $(p<0.01)$ difference for malt protein content and malt extract content for the test environments. The tested genotypes also had high significant difference for sieve test and malt extract content $(p<0.001)$ with malt moisture content showing significance at probability level $(p<0.05)$. The other quality parameters viz. grain protein content, germination energy, germination capacity, sieve test and wort color were statistically non- significant for the test environments. Therefore, it is important to pay attention to the environmental condition, like the soil type, the climate and others, where the malt barley is produced in order to get high quality malt grain.
\end{abstract}

Keywords: malt barley, variability, genotype by environment interaction

\section{INTRODUCTION}

Barley (Hordeum vulgare L.) is a versatile crop for human food, malt and livestock feed. It is the fourth most important cereal crop after wheat, rice and maize, cultivated successfully in a wide range of climate (FAO, 2005). Barley is the most dependable cereal and is cultivated on highly degraded mountain slopes giving better yield than other cereal crops in the highland of Ethiopia under extreme marginal conditions of frost and poor soil fertility (Ceccarelli et al., 1999). Temperature and rainfall differences coupled with edaphic factors create a wide range of ecological conditions in the country.

Analysis of variability among the agronomic traits and the association of a particular character in relation to other traits contributing to yield of a crop would be of great importance in planning a successful breeding program. The magnitude of genetic variability present in base population of any crop species is pivotal to crop improvement which must be exploited by plant breeders for yield improvement (Idahosa et al., 2010). Development of high-yielding cultivars requires a thorough knowledge of the existing genetic variation for yield and its components. The observed variability is a combined estimate of genetic and environmental causes, of which only the former one is heritable.

The objective of the study was to assess the total variability present within the studied genotypes.

\section{Materials ANd Methods}

The experiments were conducted at Bekoji and Kofele sub-stations of Kulumsa Agricultural Research Center (KARC) using randomized complete block design with four replications. Seeds were drilled in 
6 rows of $2.5 \mathrm{~m}$ length spaced $0.2 \mathrm{~m}$ apart. The seed rate, Di- ammonium phosphate and urea fertilizers were applied at rates of $100 \mathrm{kgha}^{-1}, 100 \mathrm{kgha}^{-1}$ and $50 \mathrm{kgha}^{-1}$ respectively.

\section{Description of the Study Area}

The experimental sites are located at highlands greater than 2600 masl and are experimental fields of KARC, which annually accommodate research experiments following crop rotation schemes.

\section{Experimental materials}

The experimental materials were composed of 18 promising malt barley genotypes (crosses and introductions) and 2 checks ( 1 standard and 1 local), a total of 20 genotypes (Appendix Table 1). The crosses were made at KARC from the materials that were released/ and from accessions maintained by Ethiopian Institute of Agricultural Research (EIAR) in the past years. The introductions, on the other hand, consisted of materials that are introduced from different sources, mostly from ICARDA.

\section{RESULTS AND DISCUSSION}

The combined analysis of variance of 15 agronomic and physical seed character related traits is given in Table 1. The results from the combined analysis indicated that there were significant differences among the tested genotypes for days to heading, days to maturity, grain yield, fertile tillers per plant, total tillers per plant, spike length and number of kernels per spike $(\mathrm{P}<0.001)$. The existence of significant variations for these traits was reported by Tiegist et al. (2010) and Singh (2011). The tested genotypes had different significance levels for different characters and similar findings were reported by Jalata et al. (2011). Days to heading, days to maturity, grain yield, biomass weight, fertile tillers per plant, total tillers per plant, spike length and number of kernels per spike significantly differed for the tested genotypes $(\mathrm{p}<0.001)$. This result is in accordance with the result reported by Berhane and Alemayehu (2011). Plant height, thousand kernel weight, awn length and hectoliter weight were significantly different among the tested genotypes $(\mathrm{p}<0.01)$. Yosef et al. (2011) observed significant differences in days to heading, grain yield per plot and thousand kernel weight, but non-significant difference for days to maturity, plant height and biomass yield in barley.

Table 1. Combined Analysis of variance for 12 characters of 20 barley genotypes studied at Bekoji and Kofele, 2015.

\begin{tabular}{|c|c|c|c|c|c|c|c|c|c|c|c|c|c|}
\hline S.V & DF & DH & DM & PIH & TKW & HLW & YLD & BWt & FTP & TTP & SL & $\mathbf{A L}$ & NKS \\
\hline Loc & 1 & $207.03 * *$ & $4494.40 * * *$ & $1708.25 *$ & $192.50 * *$ & $241.88 * *$ & $7.48 * *$ & * $90.75 * * *$ & $\begin{array}{l}101.44 \\
* * *\end{array}$ & $196.69 * * *$ & * $1.46^{*}$ & $0.99 \mathrm{~ns}$ & $205.9 * * *$ \\
\hline Gen & 19 & $196.35^{*} *$ & * $147.98 * * *$ & $2338.31 * *$ & $303.58 *$ & $35.16 * *$ & $1.98 * *$ & $* 36.95 * * *$ & $6.99 * * *$ & $10.61 * * *$ & $5.42 * * *$ & $10.52 * *$ & $* 1469 * * *$ \\
\hline $\begin{array}{l}\text { Loc } x \\
\text { gen }\end{array}$ & $x$ & $22.76 * * *$ & $23.54 * * *$ & $35.19^{\mathrm{ns}}$ & $8.43 * *$ & $1.87^{\mathrm{ns}}$ & $1.71 * *$ & $8.30 * * *$ & $3.86 * * *$ & $4.68 * * *$ & $0.52 * *$ & $0.89^{\mathrm{ns}}$ & $12.5^{\mathrm{ns}}$ \\
\hline Error & 38 & 5.21 & 5.15 & 24.69 & 3.41 & 1.00 & 0.39 & 2.33 & 0.94 & 1.18 & 0.23 & 0.56 & 9.61 \\
\hline $\begin{array}{l}\mathrm{CV} \\
\%\end{array}$ & & 2.76 & 1.44 & 4.75 & 3.93 & 1.68 & 12.87 & 13.08 & 13.45 & 13.88 & 6.24 & 6.92 & 8.73 \\
\hline
\end{tabular}

$* * *=$ Significant at $(\mathrm{p}<0.001), * *=$ significant at $(\mathrm{p}<0.01), *=$ significant at $(\mathrm{p}<0.05) ; \mathrm{ns}=$ nonsignificant at $(\mathrm{p}<0.05)$. $\mathrm{DH}=$ days to heading; $\mathrm{DM}=$ days to maturity; $\mathrm{PlH}=$ plant height; $\mathrm{TKW}=$ thousand kernel weight; $\mathrm{HLW}=$ hectoliter weight; $\mathrm{YLD}=$ grain yield; $\mathrm{BWt}=$ biomass weight; $\mathrm{FTP}=$ fertile tillers per plant; $\mathrm{TTP}=$ total number of tillers per plant; $\mathrm{SL}=$ spike length; $\mathrm{AL}=\mathrm{awn}$ length; $\mathrm{NKS}=$ number of kernels per spike.

Table 2. Combined Analysis of variance for 9 malt quality characters of 20 barley genotypes studied at Bekoji and Kofele, 2015 


\begin{tabular}{|l|l|l|l|l|l|l|l|l|l|l|}
\hline S.V & DF & GPC & MPC & GE & GC & ST & MMC & Fr & Ex & WC \\
\hline Loc & 1 & $2.05^{\mathrm{ns}}$ & $6.49^{* * *}$ & $0.02^{\mathrm{ns}}$ & $0.06^{\mathrm{ns}}$ & $291.55^{\mathrm{ns}}$ & $9.08^{*}$ & $65.21^{* * *}$ & $65.21^{* * *}$ & $0.77^{\mathrm{ns}}$ \\
\hline Gen & 19 & $1.13^{\mathrm{ns}}$ & $1.29^{\mathrm{ns}}$ & $1.06^{\mathrm{ns}}$ & $0.66^{\mathrm{ns}}$ & $1102.07^{*} * *$ & $2.38^{*}$ & $6.06^{* * *}$ & $6.06^{* * *}$ & $1.75^{* *}$ \\
\hline Loc x gen & 19 & $0.90^{\mathrm{ns}}$ & $0.92^{\mathrm{ns}}$ & $0.69^{\mathrm{ns}}$ & $0.77^{\mathrm{ns}}$ & $170.52^{\mathrm{ns}}$ & $1.38^{*}$ & $1.85^{\mathrm{ns}}$ & $1.85^{\mathrm{ns}}$ & $0.32^{\mathrm{ns}}$ \\
\hline Error & 38 & 0.83 & 0.89 & 0.45 & 0.45 & 102.17 & 0.55 & 1.10 & 1.10 & 0.47 \\
\hline
\end{tabular}

$* * *=$ significant at $(\mathrm{P}<0.001), * *=$ significant at $(\mathrm{P}<0.01), *=$ significant at $(\mathrm{P}<0.05)$ and $\mathrm{ns}=$ nonsignificant at $(\mathrm{p}<0.05) . \mathrm{GPC}=$ grain protein content,

$\mathrm{MPC}=$ malt protein content $\mathrm{GE}=$ germination energy; $\mathrm{GC}=$ germination capacity; $\mathrm{ST}=$ sieve test; $\mathrm{MMC}=$ malt moisture content $\mathrm{Fr}=$ Friability; $\mathrm{Ex}=$ extract $\mathrm{WC}=$ wort color.

The only non-significant difference was observed between locations for awn length. The study also showed highly significant genotype $\mathrm{x}$ environment interaction for days to heading, days to maturity, grain yield, biomass weight, fertile tillers per plant, total tillers per plant $(\mathrm{p}<0.001)$ and thousand kernel weight and spike length $(p<0.01)$. Tesfahun et al. (2001) found significant differences for these traits whereas plant height, hectoliter weight, awn length and number of kernels per spike did not show significant genotype $\mathrm{x}$ environment interaction that showed these traits performed in similar fashion along the testing environments. The analysis of variance for malting quality characters studied is given in (Table 2$)$. The analysis of variance showed highly significant $(p<0.01)$ difference for malt protein content and malt extract content for the test environments. This may prove the importance of environment to have malt barley with high quality malt extract. Malt moisture content showed significance at probability level $(\mathrm{p}<0.05)$ and the other quality parameters viz. grain protein content, germination energy, germination capacity, sieve test and wort color were statistically non- significant for the test environments. This indicates that the performance of the genotypes was not affected over locations in relation to these parameters.

The tested genotypes had significant difference for sieve test and malt extract content $(\mathrm{p}<0.001)$. This result is in agreement with the finding of

Shimelis et al. (2015). This revealed the existence of high level of genetic variability among genotypes and selection of genotypes based on these traits would increase the genetic gain for malt quality characteristics. Wort color was also significant, but at $\mathrm{p}<0.01$ while malt moisture content was significant only at $\mathrm{p}<0.05$. Grain protein content, malt protein content, germination energy, germination capacity and friability showed non- significance among the tested genotypes. Significant genotype $\mathrm{x}$ environment interaction was observed only for malt moisture content $(p<0.05)$. The absence of interaction effect for other parameters showed the consistence of the relative performance of the genotypes across the testing locations.

\section{CONCLUSION}

Existence of variability in genotypes indicates high potential for effective crop improvement and/or evaluation in different environments. Evaluation of malt barley genotypes in different environments is crucially needed as the agronomic as well as the quality parameters of malt barley can be affected by environmental conditions. The effect of environment can affect both the agronomic and quality aspects of malt barley genotypes. Therefore, it is important to pay attention to the environmental condition where the malt barley is produced in order to get high quality malt grain.

\section{REFERENCES}

[1] Berhane L. and Alemayehu A. (2011). Advances and experiences in barley landrace improvement in Ethiopia. In: Mulatu, B. and Grando, S.(eds). (2011). Barley Research and Development in Ethiopia. Proceedings of the 2nd National Barley Research and Development Review Workshop: 28-30 Nov., 2006. HARC, Holeta, Ethiopia

[2] Ceccarelli S, Grando S, Shevstov V, Vivar H, Yayaoui A, El-Bhoussini M, Baum MM (1999). The ICARDA strategy for global barley improvement. Rachis 18(2):3-12.

[3] FAO (2005). Food and Agriculture Organization of the United Nations. Estimates of world production and harvested area Data from faostat.fao.org.

[4] Idahosa DO, Alika JE, Omoregie AU (2010). Genetic Variability, Heritability and Expected Genetic Advance as Indices for Yield and Yield Components Selection in Cowpea (Vigna unguiculata L.) Walp. Academia Arena 2(5):22-26. 
[5] Jalata Z, Ayana A, Zeleke H (2011). Variability, Heritability and Genetic Advance for Some Yield and Yield Related Traits in Ethiopian Barley (Hordeum vulgare L.) Landraces and Crosses. International Journal of Plant Breeding and Genetics 5(1):44-52

[6] Shimelis G, Hussein M, Berhane L (2015).Evaluation of Ethiopian Barley (Hordeum vulgare L.) Landraces for Yield, Malting Quality and Related Traits at Bekoji, Southeastern Ethiopia. MSc. Thesis, Hawassa University, Hawassa, Ethiopia.

[7] Singh AP (2011). Genetic Variability in two-rowed barley (Hordeum vulgare L.). Indian Journal of Scientific Research, pp. 21-24.

[8] Tesfahun A, Harjit S, Fekadu A (2001). Genetic Divergence and Association for Yield and Related Traits in Barley (Hordeum vulgare L.). MSc. Thesis, Alemaya University, Alemaya, Ethiopia.

[9] Tiegist DA, Andrea MB, Jens I (2010). Genetic Diversity and Population Differentiation Analysis of Ethiopian Barley (Hordeum vulgare L.)Landraces Using Morphological Traits and SSR Markers. Hereditas 147:154-164.

[10] Yosef GH, Kebede T, Senait W (2011). Achievements of food Barley breeding research for low moisture stressed environments of north east Ethiopia. In: Mulatu, B. and Grando, S.(eds). (2011). Barley Research and Development in Ethiopia. Proceedings of the 2nd National Barley Research and Development Review Workshop: 28-30

Appendix Table 1. Test genotypes and their randomization.

\begin{tabular}{|l|l|c|c|c|c|}
\hline \multicolumn{2}{|l}{ Entry Name } & \multicolumn{2}{|c|}{ Randomization by plot } \\
\cline { 3 - 6 } & RepI & RepII & RepIII & RepIV \\
\hline 1 & MB:unknown\#102 & 6 & 38 & 44 & 67 \\
\hline 2 & Miscal-21 X Bahati & 20 & 25 & 41 & 62 \\
\hline 3 & Miscal-21 X Sabini & 9 & 28 & 48 & 69 \\
\hline 4 & MB:unknown\#99 & 12 & 30 & 58 & 61 \\
\hline 5 & Miscal-21 X Karne & 11 & 21 & 59 & 79 \\
\hline 6 & Beka X HB-52 & 4 & 26 & 43 & 73 \\
\hline 7 & MB:unknown\#100 & 2 & 23 & 53 & 66 \\
\hline 8 & MB:unknown\#101 & 8 & 32 & 42 & 76 \\
\hline 9 & Miscal-21 X CDC Select & 7 & 36 & 54 & 70 \\
\hline 10 & Conchita & 5 & 33 & 52 & 78 \\
\hline 11 & FC Jeldu sps-18 & 1 & 34 & 45 & 68 \\
\hline 12 & IBON 13-98 & 18 & 37 & 60 & 64 \\
\hline 13 & IBON 13-61 & 19 & 24 & 55 & 80 \\
\hline 14 & IBON 13-42 & 15 & 22 & 57 & 74 \\
\hline 15 & FC Jeldu sps-14 & 16 & 31 & 56 & 75 \\
\hline 16 & FC Jeldu sps-4 & 17 & 27 & 49 & 63 \\
\hline 17 & FC Jeldu sps-5 & 3 & 35 & 47 & 71 \\
\hline 18 & FC Jeldu sps-16 & 10 & 39 & 46 & 72 \\
\hline 19 & Bahati & 13 & 29 & 51 & 65 \\
\hline 20 & Holker & & 50 & 77 \\
\hline
\end{tabular}

Citation: Workineh Mekasa Buli and Hussein Mohammed Ali, (2021). “Assessing genetic Variability in Malt Barley (Hordeum distichon L.) Genotypes in Southeastern Ethiopia”, International Journal of Research Studies in Agricultural Sciences (IJRSAS), 7(8), pp. 23-26 DOI: http://dx.doi.org/10.20431/24546224.0708003

Copyright: (c) 2021 Authors. This is an open-access article distributed under the terms of the Creative Commons Attribution License, which permits unrestricted use, distribution, and reproduction in any medium, provided the original author and source are credited. 